PRIFYSGOL

glyndŵn

Glyndŵr University

Glyndŵr University Research Online

Theology

Theology

$1-1-2009$

\title{
Pentecostalism and religious broadcasting
}

William K. Kay

Glyndwr University, w.kay@glyndwr.ac.uk

Follow this and additional works at: http://epubs.glyndwr.ac.uk/theo

Part of the Religious Thought, Theology and Philosophy of Religion Commons

This is a preprint of an article whose final and definitive form has been published in the Journal of Beliefs and Values 2009 copyright Taylor \& Francis. The Journal of Beliefs and Values is available online at: www.informaworld.com

\section{Recommended Citation}

Kay, W. K. (2009) 'Pentecostalism and religious broadcasting'. Journal of Beliefs and Values, 30(3), 245-254

This Article is brought to you for free and open access by the Theology at Glyndŵr University Research Online. It has been accepted for inclusion in Theology by an authorized administrator of Glyndŵr University Research Online. For more information, please contact d.jepson@glyndwr.ac.uk. 


\title{
Pentecostalism and religious broadcasting
}

\author{
William K Kay (Glyndŵr University, UK)
}

\begin{abstract}
After considering the historical emergence of religious broadcasting, this article surveys Pentecostal broadcasting in different parts of the world and seeks to estimate its influence.
\end{abstract}

Keywords: Televangelism; local radio; religion and politics; healing

Email: w.kay@glyndwr.ac.uk

\section{Introduction}

As church attendance has declined in many parts of the western world, religious broadcasting brings religion to public notice among people who would otherwise never consider entering a church building. Because of its ambiguous status as both public and private space, the radio set and television screen delineate religion in legal and cultural terms while, within the intimacy of the home, establishing a quasi-personal relationship with the faith-embodying broadcaster. Pentecostals have been part of religious broadcasting since its inception, as we shall see.

\section{The USA and the UK: basic differences}

Religious broadcasting is a technological story as well as a religious story. The early history of radio broadcasting takes place in Europe and the United States from about 1920 onwards. Initially radio was restricted to military uses and the early development in the United States was delayed by opposition from the Navy and by legal disputes over patents. Once these issues had been resolved in the United States, local radio broadcasts began to take place over areas limited by the strength of the radio transmitters (Rosen 1959, 572-581). Early transmitters had a radius of perhaps 100 miles. Only by building a series of stations, each at the edge of the range of the previous one, could the whole United States be crossed. The funding for this expansion was commercial rather than governmental. Typical radio programmes in United States were either preceded by references to sponsors or interrupted by advertising jingles. The use of air time by churches or other charitable organisations was treated as if they were commercial organisations; churches could buy air time or sponsor programmes, and generally the most evangelistic preachers found it easiest to gain funding for their gospel appeals. Direct preaching was part of the religious scene from 1924 when Aimee Semple McPherson, a Pentecostal evangelist, erected her own radio station and placed a 250 foot high transmission towers on the top of Angelus Temple, the church she had built, to give her programmes the maximum range (Sutton 2007, 78-81). Even so, religious broadcasting could only expand as fast as the market could produce cheap radio sets small enough to be installed in homes and offices. Consequently the expansion of religious radio broadcasting was dependent upon technological innovation. The same considerations applied in Europe where the strength of radio transmission and the availability of radio sets were equally necessary for growth. 
From the mid 1920s onwards Britain radio broadcasting was funded by the sale of licences to listeners. The licence fees were paid to a public corporation, the British Broadcasting Corporation, which was constituted in 1927 (Stevenson 1984, 408). British broadcasting was therefore free of commercial pressures and never carried advertising or appeals for money. ${ }^{1}$ Despite the contrasts between the climate in which American and British broadcasters operated, religion, and especially Christianity, found its way onto the BBC through cultural and moral expectations. Sunday church services were considered helpful to those who were unable to leave home and travel to a live congregation (Wolfe 1984, 5). The capacity of radio to carry voice and music from prearranged venues (like church buildings) or specialised studios shaped the style of programs being offered. Either broadcasts were made of actual services (with plenty of time being given for singing and a shorter amount of time being given for sermons) or recordings were made in studios of discussions or monologues. These technological constraints ensured religion was presented without visual symbols or silent ritual. It was essentially a verbal or musical experience. Moreover, where discussion was held, it needed to be rational, clear, generally comprehensible (without abstruse technical terms) and offering a balance of contrary opinions so as to avoid offending too many licence payers. It was they, after all, who funded the entire BBC enterprise.

Even in the United States there was support for religious broadcasting within public interest programming from the 1930s. Secular radio networks were required to allocate a small percentage of weekly airtime to public interest programs and this allowed religious groups free access to the airwaves although, because there were more groups vying for this time than could be accommodated, ecumenical bodies parcelled out the hours according to an agreed scheme. Among those who participated were Roman Catholic and Jewish groups as well as many Protestants. This system had the effect of blocking out independent nondenominational evangelicals, including Pentecostals. When regular television broadcasts began in about 1940, the same principle was applied to the allocation of air time. Consequently the National Association of Evangelicals founded its own group (the NRB) to foster its broadcasting mission. Despite attempts to muzzle the evangelistic aims of the NRB and to silence it by complaining to Congress, religious freedom was seen to be too precious a value within the United States for such tactics to be successful, especially since, after Pearl Harbour, the USA believed itself to be fighting a war for democracy, free speech and freedom of worship against all kinds of dictatorship. It would have been wrong, it was argued, to cut evangelical broadcasting in the USA when censorship was a hallmark of the twin evils of fascism and communism (Melton, Lucas and Stone 1997, 387, 388).

The sheer size of United States, as well as its five time zones, made coast-to-coast broadcasting an entirely different proposition from national broadcasting in Great Britain. But, even apart from these technical differences, the contrast between a commercially funded network, or series of networks (albeit with some public service responsibilities), and a national broadcaster funded by a licence was played out both on the political and on the religious scene. A wider range of political views could be heard on the American airwaves and a wider range of religious opinion mirrored this diversity: eventually the political and religious became interconnected. More important to the development of religious broadcasting was the sheer size and vibrancy of US Pentecostalism within the religious world. During the 1920s and 30s Pentecostal denominations within the United States began to grow, organise themselves, accumulate resources, set up publishing houses, fund radio

\footnotetext{
${ }^{1}$ This is not quite true. BBC Radio 4 does allow a short financial appeal for the 'week's good cause' on Sunday mornings.
} 
stations or buy a time to propagate their message. Nowhere else in the world did Pentecostal churches command such financial muscle or assimilate such technical expertise.

After 1945, healing evangelists, many of whom had been brought up in the Pentecostal denominations, began to break free to tour the United States with large tents to preach the 'old-time religion'. Among these was Oral Roberts (b 1918) whose huge portable tent ('a canvas cathedral') dwarfed any indoor arena and whose meetings harked back to a frontier era of sawdust trail preachers and Methodist revivalism. Although Roberts may be depicted as a religious entrepreneur, there is no doubt that he was driven by a genuine religious passion which included a desire to see miracles of healing. He had himself been healed of tuberculosis as a young man when his sister had taken him to a crusade tent to receive prayer.

When television in the United States began to show filmed versions of Oral Robert crusades, the atmosphere of the big tent was readily transferred to the small screen. Roberts first conveyed the essence of his crusade meetings after a successful experiment with fast film which could capture movement in poorly lit conditions. During the 1950s Roberts was able to reach out on TV stations so that, by 1957,35 of the 500 national TV stations carried his programme (Harrell 1985, 129). After the mid-1950s it was the technical capacity to film inside a large canvas tent and to record the preacher's voice and ambient sound on one soundtrack that made the independent Pentecostal evangelists more than marginal social figures and brought them into the living room of the urban middle class. Here was religion in the raw, separate from the formalities and rituals of Sunday worship, and, because Roberts laid hands on those who were ill, nobody knew exactly what would happen when he prayed. There was drama and excitement; this was religion as your pioneering grandfather remembered it.

In 1966/67 Roberts stunned his followers by cancelling his successful TV format. In 1968 he launched a completely new presentation of religion. He planned for a weekly series on Sundays and four one hour specials in prime time. He launched his first 'Contact' television special in March 1969 and surrounded himself with singers, minor celebrities, Christian and otherwise, and presented a magazine style form of television that was soon widely adopted. Gone was the preaching and the pulpit to be replaced by the sofa and the homely chats. His previous supporters denounced Roberts for becoming too 'worldly' but within a year he was widely copied and by 1970 received over 500,000 letters, mainly of support, in response to a single hour long programme (Harrell 1985, 269). The new pattern of religion and entertainment was admired so that in the mid-70s there were well over a hundred religious shows or programs on American television, all of them funded by appeals to viewers, all of them selling books and music, and all of them inviting interactive correspondence with their viewers.

Roberts encouraged viewers to phone-in and was one of the first to install banks of 'trained counsellors' to respond to callers. ${ }^{2}$ Religion was presented outside the arena of the crusade and outside the setting of the congregation. It became centred around a charismatic celebrityindividual surrounded with musicians and anonymous phone answerers who gave the impression that the TV preacher was interested in their personal problems.

\footnotetext{
${ }^{2}$ Pat Robertson, founder of the huge Christian Broadcasting Network, started The 700 Club in 1967, combining the talk show format with opportunities to call in for prayer or counselling. See D. E. Harrell (1987), Pat Robertson : a personal, religious and political portrait, San Francisco, Harper \& Row, p 57. It may be that Robertson slightly preceded Roberts in discovering the format.
} 
Subsequent development in religious broadcasting backtracked a little on the Roberts format so that there were later reintroductions of the crusade mode under younger evangelists like Benny Hinn (b 1952) and by fundamentalist preachers like the Moral Majority's Jerry Falwell (1933-2007). But even here, in a postmodern amalgam of styles, there was a mixture between the celebrity cult, the chat show and the big public meeting where prayer for healing accompanied glitzy evangelical preaching. By the late 1990s, multi-platform religious broadcasting could take place via websites using the internet. Here respondents could click on to websites run by religious individuals or organisations and download podcasts, video clips or streamed live data from video cams. The result was that religious broadcasting could take place 24 hours per day. The mixture of styles allowed religion to be presented in both an intimate one-to-one chat format as well as in the large congregational meeting, and the large congregational meeting could veer towards theatricality with dancing, falling over, laughing, and other physical manifestations of spirituality. In this way the morality and music of radio was supplemented or replaced by more exhibitionist styles of religiosity (Schultze, 1991,ch.4).

\section{Televangelism across the world}

As Bruce (1990) has pointed out, the withdrawal of many western missionaries after 1945 coincided with the manufacture of inexpensive mass-produced radio sets. By 1954, medium wave radio stations from Trans World Radio based in Monte Carlo could provide clear signals to almost anywhere on earth and Billy Graham's broadcasts were regularly carried. The Pentecostals were not far behind. By the end of the 1950s, Roberts had made 300 films (usually of his crusade meetings) in 16 languages and these were distributed in Central and South America and in Africa. Their effect was considerable because they reached people who had already listened to his radio broadcasts. South Africa was a case in point: in 1955 Roberts was 'stunned' by the size of the crowds attending his first campaign there (Harrell 1985, 138). He followed broadcasts or visits by the distribution of literature and the success of his venture can be gauged by the fact that he opened offices with paid staff in England, Northern Ireland, South Africa, Australia and New Zealand.

This pattern was common to all the biggest Pentecostal evangelists. They began in the United States where they could build up financial bases from which they could launch out into print, radio, film and ultimately television. If they were successful in one region of the world, they went in person and worked with local Pentecostal churches or, if there were none, funded converts who became local pastors. T L Osborn bought bicycles for Kenyan evangelists and gave them each a year's salary during which they had the chance to assemble self-sustaining congregations. In the 1950s, during the Cold War, when memories of US resistance to communism were fresh, the Philippines and South Korea (and even Japan) were especially susceptible to Pentecostal evangelism. Any huge campaign meeting in one country could be filmed and used to advertise future meetings there or shown back home in the US to stimulate further financial giving. Endlessly inventive and creative, the evangelists believed they were fulfilling a divine call to take the 'full gospel' (i.e. with miraculous attestation) to the ends of the earth.

By the 1960s educated third generation Pentecostals and charismatics emerged. Luis Palau, fluent in English and Spanish, could be heard on 380 stations throughout Latin America and the States. Other Hispanic ministries emerged in the 1970s. Anne Giminez ministers with her husband, John, a drug addict converted during the Jesus Movement (an off-shoot of the hippie era), on independent TV stations broadcasting to the Spanish-speaking world. Paul 
Finkenbinder, born to missionary parents in Puerto Rico, broadcasts from California to 27 countries in Central and South America. In Brazil the Universal Church of the Kingdom of God (UCKG) with over 2,000 congregations plunged into broadcasting. By the 1990s it had the third largest TV network in the country, a newspaper, at least 30 radio stations and a huge megachurch or 'cathedral of faith' seating 10,000 people in Río de Janeiro (Anderson, 2004,73). In the Philippines the Filipino-led Jesus is Lord Fellowship quickly built up to 500 congregations, two Bible schools and a TV station prepared to ask sharp questions of politicians. By attempting to hold politicians accountable for their behaviour and by giving their endorsement to some politicians and not to others, Pentecostal and charismatic broadcasters began to have an impact upon the electoral process. In Latin America Pentecostals were prepared to stand for political office and succeeded in gaining seats in various legislatures without wedding themselves to one political party or another. It was easier to gain support from church members on moral issues (like abortion) than economic or social policy (Kay 2009, ch 6).

In the UK the God Channel (www.god.tv) can be seen on Sky and offers many programs that have already been aired elsewhere within the world of televangelism although it does fund its own original shows. The style is dramatic, eschatological and passionate. The underlying pre-millennial theology ensures that time is given to the exposition of biblical prophecy and its alignment with events in the Middle East. Meanwhile, on the BBC, religious broadcasting remains less provocative and inclined to feature topics like 'my favourite hymn' as well as the lusty singing of songs that may have originated in charismatic contexts. The hidden politics behind the BBC's religious broadcasting has occasionally been discussed (Quicke and Quicke 1992): it appears that one purpose of these politics is to ensure evangelical and Pentecostal evangelists are kept firmly at bay.

In Australia (http://www.acctv.com.au/) Christian broadcasting belongs recognisably to the same genre and, in addition to home grown material, offers space to re-broadcasts of American or Asian shows while being willing to give space to Messianic Judaism or 'Jews for Jesus'.

In Ghana the new Pentecostal churches enjoy a commanding presence on the unregulated airwaves (Gifford 2004, 30-40). While vestiges of the BBC-like public service ethos remain in a mid-morning Sunday slot that is shared by the mainline churches, the Pentecostals and charismatics have captured the rest of the spectrum. They raise money through donations and sponsorships to screen their services and publicise their message. In Accra, TV helps to define what Christianity is though, outside the capital, FM radio is more pervasive and carries music, preaching and vivid testimony. So, while the mainline churches sink their money into education and welfare, the new churches help shape public consciousness about the supernatural. As with the American healing evangelists who discovered the pattern, large meetings can be turned into various types of broadcastable material which have the secondary purposes of facilitating the sale of books and tapes, boosting attendance and generating cash flows. And - as the testimonies demonstrate - making converts and establishing the reality of divine healing.

In Sweden changes within the ecology of broadcasting make for greater pluralism (Coleman 2000, 166-186). By the 1990s Word of Life (a neo-Pentecostal network) was making sermons and testimonies available in many formats including local radio and, for greater range, satellite. Expertise in programme-making acquired in this way has even enabled some penetration of the Swedish Broadcasting Corporation which has bought occasional packages. 
Cassettes function as books and tracts did in an earlier era: they can be given away and watched in private (where religion increasingly is thought to belong) or shared in homegroups (where songs and bible study can occur in a group setting).

The largest and most versatile broadcasting network was formed in United States in 1973 by a Pentecostal preacher, Paul Crouch (b 1934). Trinity Broadcasting Network (TBN) provides interdenominational Christian programming 24 hours a day. By 1995 its network, carried by cable and by over $500 \mathrm{TV}$ stations, reached 28 million American households and, beyond these, households in Italy, Greece, South Africa, Costa Rica, San Salvador and the West Indies (Melton, Lucas and Stone 1997, 356). By 2009 it was on 47 satellites, 5,000 radio stations and many cable companies and broadcasting in Estonia, India, Namibia, Russia, New Zealand, Australia, South America, South Africa and the South Pacific: it claims to reach $100 \mathrm{~m}$ households globally in several languages. ${ }^{3}$ The network advertises itself as offering a safe visual environment for children and families and, by designating itself as interdenominational rather than Pentecostal, attracts a wider audience than would otherwise be the case. Many of its shows are innovative and have an entertainment value while others are more typically re-runs of old-style preaching and black gospel singing. Link-ups with the trend-setting news and comment magazine, Charisma, and with popular expositors of premillennial eschatology as well as with the more dramatic healing evangelists like Benny Hinn, complete the schedule. ${ }^{4}$ Whereas these other networks might see the Pentecostal evangelists as too flamboyant or extreme, TBN is at home with them. Appeals for money tend to be restricted to twice yearly 'telethons' similar to the fund-raising tactics employed by the BBC for 'Comic Relief'.

What is less clear is whether Pentecostal broadcasting actually brings new people to faith. The evidence provided by Bruce (1990) is that those who watch Pentecostal shows tend to be women without professional qualifications. In other words, this broadcasting functions to confirm the beliefs of the churched rather than to change the beliefs of the unchurched. However, the evidence, when taken across the whole range of Pentecostal broadcasting in many countries and cultures, is complex. So varied is Pentecostal broadcasting that it now fulfils multiple functions and is watched by diverse social groups.

\section{Content}

The trajectory of broadcasting from radio to television to multiple digital platforms has made a wider range of content possible. Radio carried speech and music; television added visual images, including film; digital platforms enabled voice and image to be integrated with the ability to surf from one website to another. In the early days radio equipment was large and immobile and confined broadcasters to the studio or a prearranged location; and recording was impossible. The development of content is partly determined by the miniaturisation of recording equipment and the novel capacity to computerise graphics that can be synchronised with speech or music. All this is to say that the early preaching of radio stars and the clunky switches from speech to music to announcer have given way to silky transitions and a more seamless experience for the listener or viewer. The framing or packaging of programs is both more and less intrusive. Each channel can easily move from a talk by a single speaker to outside broadcasts to a discussion. Pentecostal broadcasters have both mimicked the ethos of secular television (the anchorman, the Oprah Winfrey style of daytime television and shopping channels) and led the way (for instance in their fund raising methods).

\footnotetext{
${ }^{3}$ See http://www.tbn.org/ (accessed 15.07.09)

${ }^{4}$ For Charisma see http://www.charismamag.com/
} 
Consequently, in its production and packaging Pentecostal broadcasting looks like secular broadcasting; but the underlying moral and religious perspective has been shifted.

Trinity Broadcasting Network makes its own programs and thereby avoids much recycling while attempting to provide coverage for the whole age range with family-friendly films or quizzes. In this respect Pentecostal broadcasting has moved from providing a distinctive religious message complete with pictures of evangelists praying for those who are ill to a subtler televisual environment where editorial policy and news are determined by a religious worldview. Pat Robertson's CBN is a good example of the way topics like religious persecution which might be ignored by a secular broadcaster can be highlighted in editorial comment by a religious broadcaster. Equally, events that appear insignificant to secular commentators might be imbued with significance to commentators whose worldview is shaped by pre-millennial expectations. Events in the Middle East are prone to an eschatological interpretation. Here, the appearance of balance on the programme is quite different from what might be expected on a secular station. Whereas a predominantly nonreligious position (e.g. on abortion or gay rights) might be tacitly presumed and then 'balanced' by a religious representative, the position is reversed on a religious channel.

More generally, Bruce (1990) probably correctly points out that there is an affinity between the epistemology of evangelical Bible preaching and the elevation of science. In both instances an apparently robust commonsense rules out finer nuances of meaning and runs counter to predominant post-modernism. When miracles are seen on TV (and Benny Hinn would regularly show people who appear to be healed in answer to prayer), materialistic scientism is implicitly challenged. Yet there is a softening of the evangelical message in that much evangelical preaching has moved away - certainly in its language - from sin and condemnation towards achievement and empowerment. The assumption is not that the viewer is stuck in sin and wallowing in poverty but rather that he, and increasingly she, is in a job and looking for promotion. In this connection preachers may address lifestyle issues. T D Jakes, popular in the black community, is keen to stress diet and exercise as an antidote to obesity and diabetes.

No account of Pentecostal broadcasting would be complete without reference to the Bakker scandal of 1987 and the Swaggart debacle a year later. Just when Pentecostal evangelists appeared to be reviving the church and challenging the secular power of modern society, Jim Bakker and his wife Tammy Faye, a successful chat show couple, were caught up in a sexual and financial scandal which, because of their high public profile, gave newscasters all over the world a juicy story. Bakker's lawyer had made a payment to a young woman to ensure her silence after he was alleged to have gained her sexual favours. Once that information was out in the open, Bakker's entire enterprise (Disney-style heritage park complete with tennis courts, swimming pools, restaurants), was scrutinised and it was soon discovered that his millionaire lifestyle was at odds with his tearful pleas for money over the air. The discovery that elderly, devout and poorly educated women had been sending their few spare dollars to an overpaid televangelist provoked genuine anger among the wider Christian public and appeared to justify the accusations of charlatanism in the secular press. Soon after the Bakkers' fall, Jimmy Swaggart, another televangelist -- and one who had berated Bakker publicly -- was himself accused of consorting with a prostitute. These two scandals hit the whole bandwagon of Pentecostal broadcasting, especially as Bakker had previously worked with TBN. Undoubtedly the mystique of the televangelists was stripped away and their political and moral credibility diminished. Bakker was imprisoned and Swaggart was 
dismissed from Assemblies of God and then lost his airtime, almost reducing his ministry to extinction (Melton, Lucas and Stone 1997, passim; Burgess and van der Maas 2003).

\section{Politics}

While Pat Robertson's quest for the American presidency in 1988 appeared to demonstrate both the strengths and weaknesses of Pentecostal broadcasting's political leverage, elsewhere in the world other conclusions might be drawn. Robertson (b 1930), the Yale-educated son of a US senator, was an unlikely affiliate of Pentecostalism but, in the 1960s, he was caught up in the charismatic movement and, after a brief period in ministry, turned his considerable entrepreneurial skills and, it must be said, his faith to the building up of a television network (Harrell 1987). From small beginnings he eventually succeeded in reaching a large number of American households and, when he observed the promising influence of what became known as the New Christian Right (or the 'Moral Majority' to use a term popularised by Jerry Falwell) on Reagan's presidential bid in 1980, he manoeuvred himself into a position where he was a candidate in 1988. After an early showing, his support faded and George Bush senior came through successfully. Robertson succeeded in obtaining 3 million voters pledged to support him but, when pollsters examined his support on individual issues, Robertson was found well behind the other candidates (Bruce 1990, 175). Even in the southern states, where he was expected to do well, he could not muster the necessary figures. Admittedly his anticipation of Armageddon, which was part of his pre-millennial eschatology, must have been scary for most American voters but, as his supporters pointed out, Ronald Reagan notionally believe something similar.

The Robertson experience either indicated that the size of the constituency of Christian broadcasters was smaller than they thought or that viewers, despite holding to Christian beliefs, voted for politicians along party lines determined by their own self-interest or socioeconomic status. One estimate (Bruce 1990, 103f) put audience size at about $8 \%$ of the US viewing population, although the figure may be considerably higher depending on how it is calculated. Less easy to quantify is the actual influence of Christian broadcasters upon the political agenda and upon the electorate. Academic commentators (e.g. Pastor, Stone and Rapoport 1999) have argued that the significance of Robertson lay in his capacity to mobilise first-time time voters who would carry their concerns over into future Republican policy (as perhaps the nomination of Sarah Palin, also Pentecostal, indicated in 2008).

In other parts of the world Pentecostal broadcasting appears sometimes to stand with and sometimes against the government. In Ghana, the Roman Catholic Church is likely to be most critical of human rights abuses whereas the new Pentecostal charismatic churches show themselves willing to 'anoint' their politicians with a theology that almost harks back to an Old Testament view of sacral kingship (Gifford 2004, 34). On the other hand, in the Hispanic world Pentecostals seem to be more willing to use their broadcasting power to hold politicians to account or, conversely, to promote the claims of preachers who cross into the political sphere.

\section{Reflection}

Pentecostals have been at the forefront of religious broadcasting since it began. Where the regulation of religious broadcasting has been light, they have managed to raise money to generate all kinds of watchable programs. While their early intentions were entirely concentrated upon evangelical salvation, later programs have become more inclusive. Even so, the typical Pentecostal evangelist, as someone who travels from place to place holding campaigns or as the pastor of a megachurch with sufficient financial resources to fund the 
production of radio or TV programmes, will characteristically make appeals to every audience to trust in Jesus.

The faithfulness of radio and television audiences is indicated by the willingness of many thousands of people to send in small donations to keep broadcasting on the air. This extensive support has led some broadcasters to cross over into the political sphere where their results have been mixed. In the States, which might have been expected to see the breakthrough, there has been little tangible success, even under Presidents like Reagan or Bush junior who theoretically accepted the moral concerns of conservative Pentecostals. In the Hispanic world, Pentecostal television appears to have been more successful although, even here, the election of Pentecostals to political office has entailed a broadening of the base of support with the consequent dilutions of Pentecostal distinctives. Whether Pentecostal broadcasting is successful in bringing new people into church, is less easy to answer: even if the majority of the audience is already converted, the shows are certainly seen by nonchurchgoers. Perhaps, what Pentecostals have managed to do most successfully is to project a supernaturalist worldview and, where they are at their best, to highlight the need for political accountability.

\section{Bibliography}

Anderson, A. H. 2004. An Introduction to Global Pentecostalism. Cambridge: Cambridge University Press.

Bruce, S. 1990. Pray TV: televangelism in America. London, Routledge.

Burgess, S.M. and Van Der Maas, E.M. 2002. The New International Dictionary of Pentecostal and Charismatic Movements. Grand Rapids: Zondervan.

Coleman, S. 2000. The Globalisation of Charismatic Christianity. Cambridge: Cambridge University Press.

Gifford, P. 2004. Ghana's New Christianity: Pentecostalism in a globalizing African economy, Indianapolis, Indiana University Press.

Harrell, David E. 1985. Oral Roberts: an American life. Bloomington: Indiana University Press, p 129.

Harrell, David E. 1987. Pat Robertson : a personal, religious and political portrait. San Francisco, Harper \& Row.

Kay, W. K. 2009. Pentecostalism. London, SCM.

Melton, J. G., Lucas, P. C. and Stone, J. R. 1997. Prime-Time Religion: an encyclopedia of religious broadcasting. Phoenix, AZ: Oryx Press.

Pastor, G. S., Stone, W. J., and Rapoport, R. B. 1999. Candidate-Centered Sources of Party Change: The Case of Pat Robertson, 1988, The Journal of Politics, Vol. 61, 2. (May, 1999), pp. 423-444.

Quicke A. and Quicke, J. 1992. Hidden Agendas: the politics of religious broadcasting in Britain 1987-1991, Virginia Beach: Dominion Kings Grant Publications.

Rosen, Philip T. 1979. 'The marvel of radio: review essay', American Quarterly, 31.4, pp. 572-581.

Schultze Quentin, J. 1991. Televangelism and American Culture. Grand Rapids, Mich, Eerdmans. ch 4.

Stevenson, John. 1984. British Society 1914-45. Harmondsworth: Penguin, p. 408. 
Sutton, M. A. 2007. Aimee Semple McPherson and the Resurrection of Christian America. London: Harvard University Press, pp. 78-81.

Wolfe, Kenneth M. 1984. The Churches and the British Broadcasting Corporation 19221956. London: SCM, p. 5 